\title{
Sustainable Soil Conservation Plan Based on the Erosion Danger Level by using Avswat 2000
}

\author{
Mohammad Bisri, Ery Suhartanto, Lily Montarcih Limantara and Marina Putri Prastuti
}

\begin{abstract}
This research conducted on the Catur sub-watershed-Kare District with the area of $190.85 \mathrm{~km}^{2}$. The study location is oriented on the Kare District-Madiun Regency which included four villages such as the Kepel, Kuwiran, Kare, and the Bodag. This research intended to study the value of erosion and sedimentation for analyzing the Erosion Danger Level (TBE). Result of the TBE analysis can be used as the base on determining the Village Soil Conservation Plan (RKTD) in the Kare District. The pparameters of the Catur sub-watershed condition during the 10 years will be processed by using the AVSWAT 2000 for producing the value of erosian and sedimentation on the Catur sub-watershed. Result shows that the Erosion Danger Level (TBE) in the Bodag village is in the level of light to heavy (21.89\%), however, in the Kuwiran village is in the level of light to heavy (14.46\%), in the Kepel village is in the level of light to moderate (22.23\%), and in the Kare village is in the level of light to moderate (41.31\%). The Village Land Conservation Plan that is applied in the Kare sub-district are conservation by the vegetative and mechanical method, however, in the Bodag village and Kuwiran by the vegetative conservation method with the regulation of land use, in the Kare village by the vegetative and mechanical conservation method with the regulation of land use and by building the two check dams, and in the Kepel village by the mechanical conservation method with building a check dam. The result is hoped as the reference for the recovery and management of the sustainable soil conservation.
\end{abstract}

Keywords: land use, erosion, sedimentation, AVSWAT 2000,

\section{INTRODUCTION}

The wealth of international reports and websites shows that there is no shortage of the interesting cases and good practices from the various sources. The organization and the individuals are often quite willing to the showcase and share their experiences in the international forum.

Manuscript published on 30 September 2019.

*Correspondence Author(s)

Mohammad Bisri, Department of Water Resources, Faculty of Engineering, University of Brawijaya, Indonesia Indonesia. Email: mbisri@ub.ac.id

Ery Suhartanto, Department of Water Resources, Faculty of Engineering, University of Brawijaya, Indonesia Indonesia. Email: erysuhartanto@yahoo.com

Lily Montarcih Limantara*, Department of Water Resources, Faculty of Engineering, University of Brawijaya, Indonesia Indonesia. Email: lilymont2001@gmail.com.

Marina Putri Prastuti, Department of Water Resources, Faculty of Engineering, University of Brawijaya, Malang, Indonesia. Email: putriprastuti@gmail.com

(C) The Authors. Published by Blue Eyes Intelligence Engineering and Sciences Publication (BEIESP). This is an open access article under the CC-BY-NC-ND license http://creativecommons.org/licenses/by-nc-nd/4.0/ conservation

In fact, the reporting experiences with the water policy and management arrangements at the international platforms can be considered the recognition of those experiences as the hallmarks of an innovative spirit and of being at being at the forefront of the water governance [1][2]. However, the land use planning is significant for the watershed conservation and management [3]. The most land use restriction strategies assume that the land use activities close to the watershed outlet must have the large impacts on the downstream environments. However, the watershed characteristics usually vary in the space; land use restrictions should depend on the multiple criteria other than the watershed vulnerability index on the distances from the subdivisions to the outlet. Therefore some analysis has to consider the geographical and the meteorological characteristics of the subdivisions in the watershed. The soil property, surface cover, land-use conditions, and the topography can influence the hydrologic responses and the pollutant transport in a watershed [4][5]..

The riverbank erosion is a complex phenomenon resulting from the various factors which affect the balance of ecosystems. It is also important from the geomorphological aspect as it also induces the changes in the river channel course and in the development of the floodplain [6][7]. The mass-failure processes constitute a significant source of the sediment in the disturbed streams, which occur due to a combination of the hydraulic and geotechnical processes that undercut the bank toes and cause the bank collapse [8]. The riverbank erosion is a natural geomorphologic process that affects the fluvial environment in many aspects: physical, ecological and socio-economical. It is the result of a complex interaction between the channel hydraulic conditions and the physical characteristics. The Soil Conservation Service estimates that less than half the new land is being farmed with adequate erosion control and some topsoil was lost from the added area. This sudden new expansion of the land under cultivation is but one of many growing threats to the earth's natural environment that conservationists fear could, have far-reaching consequences to step up the food production.

The Madiun River sub-watershed is located in the Madiun Regency, East Java Province of Indonesia, The length of Madiun River is $\pm 28 \mathrm{~km}$ and the area is $3,755 \mathrm{~km}^{2}$. The high sedimentation in the Madiun River is very threatening the sustainability of human life there. The society through their treatment of the land preparing method has contributed as well as potential to push the occurrence of natural disaster like the flood and the landslide.

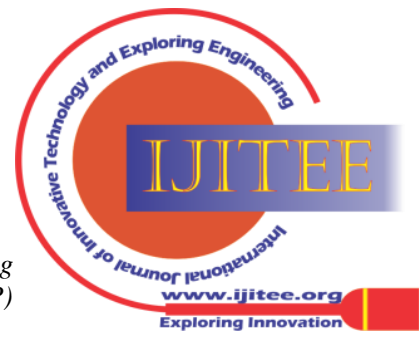


Based on the preliminary survey and workshop in the Madiun sub-watershed there is decided that the work location is oriented on the Kare District, Madiun Regency because this area is located in the upstream of reservoir. Dawuhan is as the critical area and giving the big enough of contribution for the sustainability of Dawuhan reservoir function. According to the Madiun Regency Department and Solo Watershed Development Institution, the Kare District is critical dominated. In addition, there are more happening landslide and damaged the water structures based on the preliminary survey

The objectives of this study are to know 1) the Erosion Danger Level (TBE) in the Kare District; 2) to know the Village Soil Conservation Plan (RKTD) due to the Erosion Danger Level (TBE) which can be applied in the Kare District; and 3) the planning of the sediment check dam in the
Kare District due to the Erosion Danger Lavel.. The result is hoped as the reference for the recovery and management of the sustainable soil conservation.

\section{MATERIALS AND METHODS}

\section{A. Study Location}

This study is conducted in the Catur watershed which is as one of the sub-watersheds in the Madiun watershed. Based on the preliminary study in the Madiun River watershed, it is decided that the study location is oriented on the Kare District, Madiun Regency, precisely in the four villages such as the Kepel, Kuwiran, Kare, and the Bodag. The Catur watershed represents the four villages which will be studied. Map of the location is presented as in the Fig. 1.

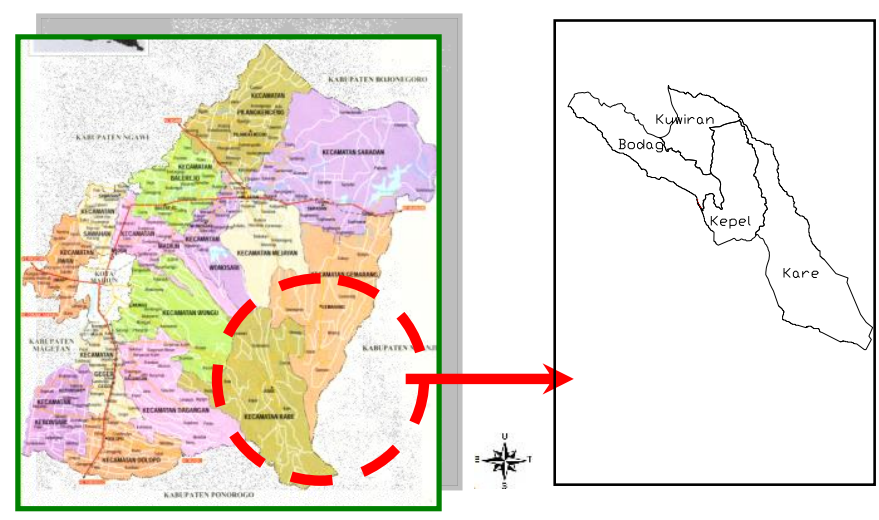

Fig. 1 The Study location

\section{B. Method of analysis}

The method of analysis which is used in this study is the AVSWAT 2000. This method is used for simulating the rainfall analysis that produces the value of erosion and sedimentation in the location study. Map of the land use is used as the input data on the AVSWAT 2000. Based on the results, it can be analyzed the Erosion Danger Level (TBE) and then it can be determined the Village Soil Conservation Plan (RKTD) there.

\section{Hydrology and ecosystem of the watershed}

Hydrology is a science which studies water in the iquid, gas, and solid form in and over the ground level, included in it, is the distribution, cycle, and the behavior; the physical and the chemical characteristic; and the relation with life unsures in the water itself [9]. However, hydrology of the watershed itself is as a branch of the hydrological science which studies the management effect of vegetation and area in the upper water catchment due to the water cycle included the effect of erosian, water quality, flood, and climate in the upstream and downstream [9]

\section{Erosion}

Hydrological process in nature will directly or indirectly be related with the happening of erosion, sediment transport, sediment deposit in the downstream and it influences the physical, chemical, and the biological characteristic which in overall represents the status of water quality. Generally, the hapening of erosion is determined by the factors of climate (mainly rainfall intensity), topography, soil characteristic, soil cover, and the land use. However, erosion is a case on the soil scrapped or part of the soil in a place that is moved to the other place which is caused by the water moving or wind [10][11].

\section{E. MUSLE (Modified Universal Soil Loss Equation)}

The Modified Universal Soil Loss Equation is as follow [12]:

sed $=11.8 \cdot\left(Q_{\text {surf }} \cdot q_{\text {peak }} \cdot \text { area }_{\text {hru }}\right)^{0.56} \cdot K_{U S L E} \cdot C_{U S L E} \cdot P_{U S L E} \cdot L S_{U S L E} \cdot C F R G$

Where:

sed $\quad=$ sediment yield per-day (ton)

$\mathrm{Q}_{\text {surf }} \quad=$ volume of the surface run-off $(\mathrm{mm} / \mathrm{ha})$

$\mathrm{q}_{\text {peak }}=$ peak run-off rate $\left(\mathrm{m}^{3} / \mathrm{s}\right)$

area $_{\text {hru }} \quad=$ hydrologic response unit (ha)

$\mathrm{K}_{\mathrm{USLE}} \quad=$ factor of the soil erodibility (USLE)

$\mathrm{C}_{\mathrm{USLE}} \quad=$ factor of the cropping method (USLE)

$\mathrm{P}_{\mathrm{USLE}} \quad=$ factor of the soil conservation practice

(USLE)

LS $_{\text {USLE }} \quad=$ factor of the topography (USLE)

$\mathrm{CFRG}=$ factor of the rude stone breaking

\section{F. Erosion Danger Level (TBE)}

The Erosion Danger Level (TBE) is obtained by comparing the erosion level on a unit of area with the effective depth. The classification of the erosion danger can be seen as in the Table- I

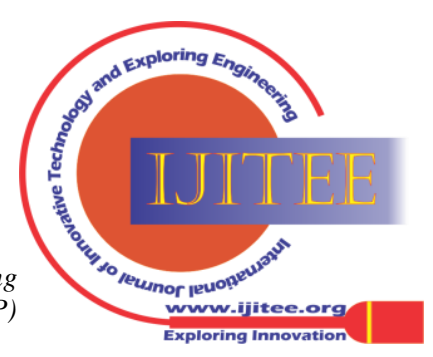


Table- I The classification of Erosion Danger Level

\begin{tabular}{|c|c|c|c|c|c|}
\hline Erosion & \multicolumn{5}{|c|}{ Class of erosion danger (ton/ha/year) } \\
\hline Soil solum $(\mathrm{cm})$ & $\begin{array}{c}\mathrm{I} \\
(<15)\end{array}$ & $\begin{array}{c}\text { II } \\
15-60)\end{array}$ & $\begin{array}{c}\text { III } \\
(60-180)\end{array}$ & $\begin{array}{c}\text { IV } \\
(180-480)\end{array}$ & $\begin{array}{c}\mathrm{V} \\
(>180)\end{array}$ \\
\hline A. Deep $(>90)$ & SR & $\mathrm{R}$ & $\mathrm{S}$ & $\mathrm{B}$ & SB \\
\hline B. Moderate (60-90) & $\mathrm{R}$ & $S$ & B & SB & SB \\
\hline C. Shallow (30-60) & $\mathrm{S}$ & $\mathrm{B}$ & SB & SB & SB \\
\hline D. Very shallow $(<30)$ & $\mathrm{B}$ & SB & SB & SB & SB \\
\hline
\end{tabular}

Source: Utomo [13]

Explanation: $\mathrm{SR}=$ very light; $\mathrm{R}=$ light; $\mathrm{S}=$ moderate; $\mathrm{SB}=$ very heavy; $\mathrm{B}=$ heavy

\section{G. Conservation effort}

Soil conservation is an effort which is carried out for solving the erosion problem. To make effort for preventing or controlling the erosion, it has to be attended some factors which influence the happening of erosion. The effort of soil conservation can be carried out by using the vegetative or

The vegetative method is a method that is used for decreasing the rainfall damaged force which is dropped and causes the surface run-off [14][15][16] and erosion by using the plant or the rest of plant [17]. In implementation, the vegetate method can include the activities like the reboisation, strip cropping, crop rotation, and serasah usage [18].

The mechanical method is as the whole mechanical-physical treatments that are given to the soil and structure building for decreasing the surface run-off and erosion, and increasing the ability of soil usage. This method consists of the drainage channel, terrace-ring, check dam, penetration well, etc.

\section{H. Check Dam}

Check dam is a controlled structure which is made because there is the water flow with the high enough of sediment concentration where is the sediment is come from the soil erosion on the upstream of river. The basic item in designing the check dam is how far the sediment is late and to be held by the structure. The design of the overflowed dimension based on the Indonesian National Standard (SNI 03-2851-1992) [19] is as follow:

\section{Design of the main dam overflowed width}

To calculate the main dam overflowed width, it is used the formula as follow:

$$
B_{1}=a \cdot \sqrt{Q_{d}}
$$

Where:

B1 = overflowed width $(\mathrm{m})$

$\mathrm{Qd}=$ design flood $\left(\mathrm{m}^{3} / \mathrm{s}\right)$

$\mathrm{a} \quad=$ run-off coefficient

Analysis of the overflowed dimension uses the formula as follow:

Where:

$Q_{d}=\operatorname{design}$ flood $\left(\mathrm{m}^{3} / \mathrm{s}\right)$

$C_{d}=$ overflowed coefficient $(0.6-0.66)$

$g \quad=$ gravitation $\left(9.8 \mathrm{~m} / \mathrm{s}^{2}\right)$

$B_{1} \quad=$ overflowed width in the low part (m)

$B_{2} \quad$ = width of water level in the upper overflowed ( $\left.\mathrm{m}\right)$

$h_{3} \quad=$ water depth over the overflowed $(\mathrm{m})$

$w \quad=$ free board $(\mathrm{m})$

$\mathrm{m}=$ slope of the overflowed edge mechanical method.

$$
Q_{d}=(2 / 15) \cdot C \cdot \sqrt{2 g} \cdot\left(3 B_{1}+2 B_{2}\right) \cdot h_{3}^{3 / 2}
$$

If $\mathrm{C}=0.60$ dan $\mathrm{m}=0.5$, the formula above becomes as:

$Q_{d}=\left(0,71 h_{3}+1,77 B_{1}\right) \cdot h_{3}^{3 / 2}$

\section{J. Overflowed mercu width}

The overflowed mercu width has to be calculated due to the stability side and the possibility of damage as the impact of the debris flow hydraulic. If it is determined by the formula, the mercu width is as follow:

$b=n / f \cdot \gamma_{w} / \gamma_{c}(t+\Delta t / 2) \cdot\left(1+4 V^{2} / 100\right)$

Where:

$b \quad$ = width of the overflowed mercu $(\mathrm{m})$

$n \quad=$ safety coefficient

$f=$ the friction coefficient on the weir point $(0.80)$

$\gamma_{w}=$ volume-weight of the water $\left(1-1.2 \mathrm{t} / \mathrm{m}^{3}\right)$

$\gamma_{c}=$ volume-weight of the weir $\left(\mathrm{t} / \mathrm{m}^{3}\right)$

$t=$ head of the water level over mercu (m)

$\Delta t=$ depth of scouring in front of the mercu (m)

$V=$ flow velocity when flooding $(\mathrm{m} / \mathrm{s})$

$Q=\operatorname{design}$ flood $\left(\mathrm{m}^{3} / \mathrm{s}\right)$

$A=$ area of wet section on overflowed $\left(\mathrm{m}^{2}\right)$

$V=Q / A$

$b=n / f \cdot \gamma_{w} / \gamma_{c}(t+\Delta t / 2) \cdot\left(1+4 V^{2} / 100\right)$

\section{$\mathrm{K}$. To determine the slope of upstream}

The slope of upper main weir is determined so the water flow does not hug the upstream surface. The ratio of vertical and horizontal is $1: n$, the standard value of $n$ index $=0.2$ or $n$ can be determined by the formula as follow:

$n_{\max }=V_{g} \sqrt{2 H / g}$

Where:

$n_{\max }=$ slope of the upper main weir/ dam body

$V_{g} \quad=$ horizontal component for the critical velocity $(\mathrm{m} / \mathrm{s})$

$H=$ total height of the main weir/ dam (m)

$g \quad=$ gravitation $\left(\mathrm{m} / \mathrm{s}^{2}\right)$

\section{To determine the slope of upstream weir (m)}

The slope of upstream main weir/ dam has to be determined based on the main stability condition and it uses the formula as follow:

$(1+\alpha) m^{2}+\{2(n+\beta)+n(4 \alpha+\gamma)+2 \alpha \beta\} m-\left\{(1+3 \alpha)+\alpha \beta(4 n+\beta)+\gamma\left(3 n \beta+\beta^{2}+n^{2}\right)\right\}=0(9)$

Published By:

Blue Eyes Intelligence Engineering and Sciences Publication (BEIESP)

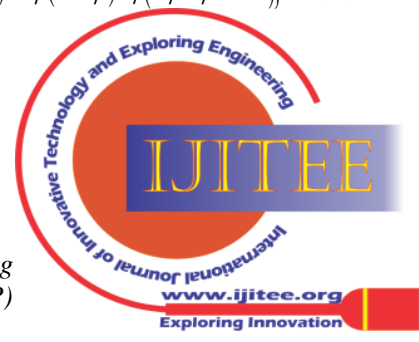


$\alpha=h_{3} / H ; \beta=b_{1} / H ; \gamma=\gamma_{c} / \gamma_{w}$

$m=\frac{-b \pm \sqrt{b^{2}-4 a c}}{2 a}$

\section{Where:}

$m$ = the body slope of the upstream main weir/ dam

$n$ = the body slope of the downstream main weir/ dam

$\alpha=$ the ratio between the water head over the overflowed and he check dam head of the river bed

$\beta=$ the ratio between the overflowed mercu width and the check dam head of the river bed

$\gamma=$ the ratio between $\gamma_{c}$ and $\gamma_{w}$

\section{To determine floor thickness of stilling basin}

The floor thickness of stilling basin is determined due to the formula as follow:

$t=0,1\left(0,6 H_{1}+3 h_{3}-1\right)$

Where:

$\mathrm{t} \quad=$ the floor thickness of stilling basin $(\mathrm{m})$

$\mathrm{H}_{1}$ = the main weir/ dam height from the stilling basin bed

$\left(\mathrm{H}_{1}=\mathrm{H}\right)(\mathrm{m})$

$\mathrm{h}_{3}=$ the water head over the overflowed of main weir/ dam (m)

N. To determine the distance between the main weir dam and the sub-dam

The length of the stilling basin is as the distance between the main dam and the sub dam and it is determined by the formula as follow:

- The formula of hydraulic experiment

$L=l_{w}+x \cdot b_{2}$

$H_{l}=H-t$

$l_{W}=\frac{V_{o}\left(H_{1}+\frac{1}{2} h_{W}\right)^{\frac{1}{2}}}{g}$

$x=\beta h_{j}$

$h_{j}=\left(h_{1} / 2\right)\left(\sqrt{1+8 F_{r 1}^{2}-1}\right)$

$F_{r 1}=\frac{V_{1}}{\sqrt{2 g \cdot h_{1}}}$

$h_{1}=q_{1} / V_{l}$

$q_{0}=Q_{d} / B_{m}$

$V_{1}=\sqrt{2 g\left(H_{1}+h_{w}\right)}$

Where:

$L \quad=$ the distance between the main dam and the sub dam

Table- II Recapitulation of erosion rate on the period of 1 January $2001-31$ December 2010 due to the land use of 2005

\begin{tabular}{|c|c|c|c|c|c|c|c|c|c|c|c|c|c|}
\hline \multirow{2}{*}{$\begin{array}{l}\text { Sub- } \\
\text { Water } \\
\text { shed }\end{array}$} & \multirow{2}{*}{$\begin{array}{l}\text { Area } \\
\text { (ha) }\end{array}$} & \multicolumn{10}{|c|}{ Erosion rate (ton/ha/year) } & \multirow[t]{2}{*}{ Total } & \multirow[t]{2}{*}{ Mean } \\
\hline & & 2001 & 2002 & 2003 & 2004 & 2005 & 2006 & 2007 & 2008 & 2009 & 2010 & & \\
\hline 1 & 58.8 & 68.15 & 33.25 & 33.55 & 18.46 & 17.503 & 24.52 & 30.35 & 13.11 & 6.63 & 16.71 & 262.21 & 47.68 \\
\hline 2 & 313.0 & 232.73 & 95.80 & 105.73 & 77.07 & 84.25 & 88.96 & 152.48 & 75.91 & 37.49 & 112.70 & 1063.12 & 193.29 \\
\hline 3 & 524.1 & 95.89 & 53.62 & 39.48 & 21.10 & 23.27 & 23.27 & 38.93 & 18.82 & 10.02 & 23.29 & 347.70 & 63.22 \\
\hline 4 & 1050.8 & 698.09 & 56.04 & 67.16 & 82.39 & 64.62 & 78.94 & 61.55 & 48.75 & 80.91 & 94.72 & 1333.16 & 242.39 \\
\hline 5 & 486.0 & 954.11 & 56.22 & 51.99 & 67.49 & 56.43 & 74.13 & 56.65 & 44.65 & 46.23 & 66.60 & 1474.51 & 368.09 \\
\hline 6 & 507.3 & 257,91 & 84,34 & 76.40 & 53.98 & 41.95 & 49.27 & 64.78 & 44.38 & 21.44 & 52.69 & 747.15 & 135.85 \\
\hline 7 & 221.0 & 193.03 & 73.43 & 47.58 & 32.51 & 37.03 & 32.33 & 51.46 & 27.57 & 13.34 & 30.89 & 539.16 & 98.03 \\
\hline 8 & 257,7 & 375.21 & 29.45 & 27.31 & 35.49 & 32.40 & 29.96 & 28.11 & 21.47 & 20.70 & 35.26 & 635.34 & 115.52 \\
\hline 9 & 1058.8 & 60.59 & 9.83 & 5.48 & 5.12 & 4.51 & 5.16 & 7.28 & 3.47 & 1.35 & 3.49 & 106.29 & 19.33 \\
\hline 10 & 379.1 & 35.01 & 4.17 & 2.16 & 2.49 & 2.17 & 2.20 & 3.62 & 1.37 & 0.62 & 1.40 & 55.22 & 19.33 \\
\hline 11 & 17.9 & 164.73 & 1.94 & 1.64 & 1.68 & 2.16 & 2.10 & 1.08 & 1.26 & 1.95 & 2.13 & 180.66 & 32.85 \\
\hline
\end{tabular}

energy equation (hydraulic) as follow: empiric.

$\frac{d}{h_{1}}=\left[\frac{\left\{\left(1+2 F_{r 1}{ }^{2}\right) \times\left(1+8 F_{r 1}{ }^{2}\right)^{1 / 2}-5 F_{r 1}{ }^{2}-1\right\}}{\left\{\left(1+4 F_{r 1}{ }^{2}\right)-\left(1+8 F_{r 1}{ }^{2}\right)^{1 / 2}-1,5 F_{r 1}{ }^{2 / 3}\right\}}\right] \ldots$ hydraulic

Where:

$d=$ the height of sub dam $(\mathrm{m})$

$F_{r l}=$ Froude number on the plunge point

Where:

$\mathrm{H}_{2} \quad$ = the height of sub dam

\section{RESULTS AND DISCUSSION}

\section{A. The simulation result of erosion and sedimentation}

The analysis of erosion and sedimentation in the Catur watershed is carried out by using the AVSWAT 2000. It is are changed every year due to the rainfall which is happened. The results are presented as in the Table Ii, III, IV, and V. January 2010) indicates that the erosion and sedimentation 


\begin{tabular}{|c|c|c|c|c|c|c|c|c|c|c|c|c|c|}
\hline 12 & 382.8 & 91.72 & 13.74 & 7.95 & 7.42 & 6.21 & 8.14 & 11.54 & 5.02 & 2.03 & 5.12 & 158.87 & 28.89 \\
\hline 13 & 120.1 & 548.02 & 37.73 & 44.08 & 39.45 & 39.0 & 55.77 & 27.96 & 32.37 & 40.26 & 54.80 & 919.43 & 167.17 \\
\hline 14 & 462.1 & 29.29 & 6.62 & 3.76 & 4.74 & 3.89 & 4.32 & 6.12 & 2.77 & 1.01 & 3.08 & 65.59 & 11.93 \\
\hline 15 & 404.8 & 49.30 & 5.11 & 6.19 & 5.99 & 4.64 & 5.76 & 4.73 & 2.98 & 5.12 & 5.84 & 95.65 & 17.39 \\
\hline 16 & 101.9 & 33.83 & 0.98 & 0.41 & 0.26 & 0.22 & 0.20 & 0.31 & 0.15 & 0.06 & 0.17 & 36.60 & 6,65 \\
\hline 17 & 9.7 & 39.54 & 1.15 & 0.48 & 0.30 & 0.26 & 0.24 & 0.36 & 0.18 & 0.07 & 0.20 & 42.77 & 7.78 \\
\hline 18 & 358.2 & 182.55 & 27.16 & 15.70 & 15.00 & 12.69 & 15.62 & 21.08 & 10.08 & 3.80 & 10.51 & 314.19 & 57.13 \\
\hline 19 & 1643.6 & 243,26 & 53.14 & 24.96 & 24.41 & 19.88 & 19.64 & 37.33 & 15.37 & 4.57 & 14.77 & 457.33 & 83.15 \\
\hline 20 & 635.1 & 316.70 & 48.72 & 24.54 & 22.83 & 19.27 & 20.12 & 34.02 & 14.32 & 4.74 & 14.60 & 519.84 & 94.52 \\
\hline 21 & 359.9 & 213.60 & 19.08 & 10.30 & 8.45 & 7.05 & 6.30 & 9.61 & 5.64 & 1.69 & 6.26 & 287.97 & 52.36 \\
\hline 22 & 1332.8 & 309.98 & 44.22 & 23.21 & 21.93 & 21.16 & 21.00 & 31.76 & 15.90 & 5.12 & 15.72 & 508.99 & 92.54 \\
\hline 23 & 862.1 & 281.02 & 47.30 & 22.18 & 22.92 & 18.85 & 17.79 & 34.40 & 13.65 & 4.21 & 14.18 & 475.88 & 86.52 \\
\hline
\end{tabular}

Source: own study

Table- III Recapitulation of sedimentation on the period of 1 January 2001 - 31 December 2010 due to the land use of 2005

\begin{tabular}{|c|c|c|c|c|c|c|c|c|c|c|c|c|c|}
\hline \multirow{2}{*}{$\begin{array}{l}\text { Sub- } \\
\text { Water } \\
\text { shed }\end{array}$} & \multirow{2}{*}{$\begin{array}{l}\text { Area } \\
\text { (ha) }\end{array}$} & \multicolumn{10}{|c|}{ sedimentation (ton/ha/year) } & \multirow{2}{*}{ Total } & \multirow{2}{*}{ Mean } \\
\hline & & 2001 & 2002 & 2003 & 2004 & 2005 & 2006 & 2007 & 2008 & 2009 & 2010 & & \\
\hline 1 & 58.80 & 25.90 & 19.68 & 17.11 & 8.47 & 8.57 & 11.01 & 12.88 & 8.44 & 3.75 & 8.93 & 124.74 & 12.47 \\
\hline 2 & 313.00 & 31.08 & 21.06 & 18.99 & 9.65 & 10.27 & 12.83 & 16.44 & 10.55 & 4.79 & 11.90 & 145.56 & 14.76 \\
\hline 3 & 524.10 & 20.92 & 16.05 & 14.55 & 7.51 & 7.44 & 8.96 & 10.82 & 7.13 & 3.12 & 7.84 & 104.34 & 10.43 \\
\hline 4 & 1050.80 & 144.28 & 10.02 & 10.30 & 10.09 & 10.03 & 10.98 & 7.00 & 7.78 & 8.24 & 12.28 & 230.99 & 23.10 \\
\hline 5 & 486.00 & 293.91 & 36.73 & 39.17 & 38.70 & 37.91 & 42.02 & 27.22 & 30.00 & 31.86 & 48.49 & 626.01 & 62.60 \\
\hline 6 & 507.30 & 26.19 & 5.01 & 4.58 & 2.04 & 2.05 & 2.95 & 3.61 & 2.58 & 1.19 & 2.97 & 53.17 & 5.32 \\
\hline 7 & 221.00 & 15.01 & 4.48 & 4.02 & 1.74 & 1.74 & 2.41 & 2.83 & 1.93 & 0.87 & 2.16 & 32.18 & 3.72 \\
\hline 8 & 257.70 & 151.81 & 20.68 & 21.90 & 21.44 & 20.86 & 23.23 & 15.02 & 16.43 & 17.24 & 26.12 & 334.73 & 33.47 \\
\hline 9 & 1058.80 & 11.19 & 3.19 & 1.35 & 1.64 & 1.60 & 1.81 & 2.37 & 1.20 & 0.39 & 1.12 & 25.85 & 2.58 \\
\hline 10 & 379.10 & 7.74 & 2.28 & 0.97 & 1.30 & 1.21 & 1.41 & 1.82 & 0.88 & 0.29 & 0.81 & 18.72 & 1.87 \\
\hline 11 & 17.90 & 115.96 & 1.66 & 1.32 & 1.28 & 1.52 & 1.51 & 0.84 & 1.07 & 1.23 & 1.63 & 128.01 & 12.80 \\
\hline 12 & 382.80 & 18.31 & 5.67 & 2.38 & 2.67 & 2.75 & 3.06 & 4.04 & 2.13 & 0.68 & 1.99 & 43.67 & 4.37 \\
\hline 13 & 120.10 & 227.01 & 18.50 & 19.56 & 19.26 & 19.44 & 21.73 & 13.94 & 15.22 & 16.48 & 24.33 & 395.48 & 39.55 \\
\hline 14 & 462.10 & 13.17 & 1.89 & 0.75 & 0.97 & 0.93 & 1.08 & 1.42 & 0.69 & 0.22 & 0.62 & 21.73 & 2.17 \\
\hline 15 & 404.80 & 23.93 & 3.14 & 3.23 & 2.98 & 2.78 & 3.32 & 2.07 & 1.96 & 2.19 & 3.17 & 48.74 & 4.87 \\
\hline 16 & 101.90 & 20.07 & 0.87 & 0.33 & 0.22 & 0.23 & 0.20 & 0.31 & 0.19 & 0.05 & 0.16 & 22.30 & 2.23 \\
\hline 17 & 9.70 & 19.81 & 0.84 & 0.31 & 0.21 & 0.22 & 0.20 & 0.31 & 0.19 & 0.05 & 0.16 & 22.30 & 2.23 \\
\hline 18 & 358.20 & 40.03 & 4.51 & 1.80 & 1.61 & 1.81 & 1.90 & 2.61 & 1.49 & 0.45 & 1.37 & 57.57 & 5.76 \\
\hline 19 & 1643.60 & 98.54 & 36.69 & 17.79 & 12.80 & 15.70 & 16.23 & 20.52 & 12.42 & 4.50 & 13.54 & 248.74 & 24.87 \\
\hline 20 & 635.10 & 130.03 & 31.26 & 16.81 & 11.62 & 14.56 & 15.26 & 17.70 & 10.37 & 4.61 & 12.57 & 264.80 & 26.48 \\
\hline 21 & 359.90 & 80.67 & 13.38 & 6.52 & 4.57 & 5.38 & 5.26 & 5.98 & 3.97 & 1.78 & 5.20 & 132.73 & 13.27 \\
\hline 22 & 1332.80 & 232.69 & 62.73 & 34.16 & 34.54 & 29.31 & 31.12 & 36.49 & 21.53 & 9.82 & 26.74 & 508.13 & 50.81 \\
\hline 23 & 862.10 & 210.11 & 51.16 & 27.48 & 19.07 & 24.18 & 25.73 & 30.16 & 17.81 & 8.13 & 22.05 & 435.87 & 43.59 \\
\hline
\end{tabular}

Source: own study

Table- IV Recapitulation of erosion rate on the period of 1 January 2001 - 31 December 2010 due to the land use of 2010

\begin{tabular}{|c|c|c|c|c|c|c|c|c|c|c|c|c|c|}
\hline \multirow{2}{*}{$\begin{array}{l}\text { Sub- } \\
\text { Water } \\
\text { Shed }\end{array}$} & \multirow{2}{*}{$\begin{array}{l}\text { Area } \\
\text { (ha) }\end{array}$} & \multicolumn{10}{|c|}{ Erosion rate (ton/ha/year) } & \multirow[t]{2}{*}{ Total } & \multirow[t]{2}{*}{ Mean } \\
\hline & & 2001 & 2002 & 2003 & 2004 & 2005 & 2006 & 2007 & 2008 & 2009 & 2010 & & \\
\hline 1 & 58.8 & 68.15 & 33.25 & 33.55 & 18.46 & 17.503 & 24.52 & 30.35 & 13.11 & 6.63 & 16.71 & 262.21 & 26.22 \\
\hline 2 & 313.10 & 143.26 & 45.24 & 42.88 & 24.97 & 26.26 & 23.72 & 30.35 & 22.32 & 7.71 & 26.07 & 392.78 & 39.28 \\
\hline 3 & 524.10 & 189.89 & 103.81 & 104.49 & 66.98 & 89.11 & 82.05 & 164.09 & 74.67 & 40.83 & 105.22 & 1015.13 & 101.51 \\
\hline 4 & 1050.80 & 698.09 & 55.90 & 67.30 & 81.32 & 65.57 & 74.04 & 55.02 & 49.53 & 75.87 & 94.99 & 1317.62 & 131.76 \\
\hline 5 & 485.90 & 1015.52 & 55.56 & 51.60 & 68.20 & 55.91 & 73.39 & 56.19 & 44.54 & 52.35 & 71.37 & 1544.62 & 154.46 \\
\hline 6 & 507.30 & 300.16 & 100.77 & 97.99 & 69.46 & 60.62 & 70.67 & 105.46 & 62.72 & 31.29 & 79.13 & 978.27 & 97.83 \\
\hline 7 & 220.90 & 177.24 & 72.54 & 47.08 & 32.23 & 36.83 & 32.11 & 51.05 & 27.34 & 13.23 & 30.59 & 520.25 & 52.03 \\
\hline 8 & 257.80 & 369.09 & 29.35 & 27.19 & 35.31 & 31.88 & 30.05 & 27.71 & 21.82 & 20.75 & 35.29 & 628.45 & 62.85 \\
\hline 9 & 1058.90 & 61.44 & 9.23 & 5.58 & 5.10 & 4.50 & 5.37 & 7.70 & 3.43 & 1.32 & 3.42 & 107.08 & 10.71 \\
\hline 10 & 379.10 & 35.01 & 4.18 & 2.15 & 2.48 & 2.24 & 2.02 & 3.51 & 1.47 & 0.52 & 1.46 & 55.05 & 5.51 \\
\hline 11 & 17.90 & 164.73 & 1.94 & 1.64 & 1.68 & 2.16 & 2.10 & 1.08 & 1.26 & 1.95 & 2.13 & 180.66 & 18.07 \\
\hline 12 & 382.70 & 91.72 & 13.73 & 7.95 & 7.60 & 6.41 & 7.87 & 10.60 & 5.07 & 1.91 & 5.44 & 158.30 & 15.83 \\
\hline 13 & 120.10 & 548.02 & 37.73 & 44.08 & 39.45 & 39.00 & 55.77 & 27.96 & 32.37 & 40.26 & 54.80 & 919,43 & 91.94 \\
\hline 14 & 462.20 & 29.29 & 6.62 & 3.76 & 4.74 & 3.89 & 4.32 & 6.12 & 2.77 & 1.01 & 3.08 & 65.59 & 6.56 \\
\hline 15 & 404.90 & 49.30 & 5.11 & 6.19 & 5.99 & 4.64 & 5.76 & 4.73 & 2.98 & 5.12 & 5.84 & 95.65 & 9.57 \\
\hline 16 & 101.90 & 33.83 & 0.98 & 0.41 & 0.26 & 0.22 & 0.20 & 0.31 & 0.15 & 0.06 & 0.17 & 36.60 & 3.66 \\
\hline 17 & 9.7 & 39.54 & 1.15 & 0.48 & 0.30 & 0.26 & 0.24 & 0.36 & 0.18 & 0.07 & 0.20 & 42.77 & 4.28 \\
\hline 18 & 358.20 & 182.55 & 27.16 & 15.70 & 15.00 & 12.69 & 15.62 & 21.08 & 10.08 & 3.80 & 10.51 & 314.19 & 31.42 \\
\hline 19 & 1643.60 & 243.26 & 53.14 & 24.96 & 24.41 & 19.88 & 19.64 & 37.32 & 15.37 & 4.57 & 14.77 & 457.33 & 45.73 \\
\hline 20 & 635.20 & 316.70 & 48.72 & 24.54 & 22.83 & 19.27 & 20.10 & 34.00 & 14.32 & 4.74 & 14.60 & 519.81 & 51.98 \\
\hline 21 & 359.90 & 213.60 & 19.08 & 10.30 & 8.45 & 7.05 & 6.30 & 9.61 & 5.64 & 1.69 & 6.26 & 287.97 & 28.80 \\
\hline 22 & 1332.90 & 308.98 & 44.21 & 23.21 & 21.93 & 21.16 & 21.00 & 31.76 & 15.90 & 5.12 & 15.72 & 508.99 & 50.90 \\
\hline 23 & 862.10 & 281.02 & 47.30 & 22.18 & 22.29 & 18.85 & 17.79 & 34.40 & 13.65 & 4.21 & 14.18 & 475.88 & 47.59 \\
\hline
\end{tabular}

Source: own study

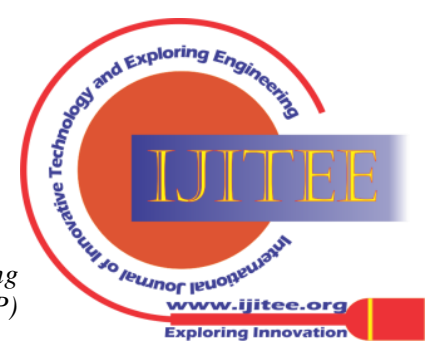


able- V Recapitulation of sedimentation on the period of 1 January 2001 - 31 December 2010 due to the land use of 2010

\begin{tabular}{|c|c|c|c|c|c|c|c|c|c|c|c|c|c|}
\hline \multirow{2}{*}{$\begin{array}{l}\text { Sub- } \\
\text { Water } \\
\text { Shed }\end{array}$} & \multirow{2}{*}{$\begin{array}{l}\text { Area } \\
\text { (ha) }\end{array}$} & \multicolumn{10}{|c|}{ sedimentation (ton/ha/year) } & \multirow[t]{2}{*}{ Total } & \multirow[t]{2}{*}{ Mean } \\
\hline & & 2001 & 2002 & 2003 & 2004 & 2005 & 2006 & 2007 & 2008 & 2009 & 2010 & & \\
\hline 1 & 58.80 & 25.90 & 19.68 & 17.11 & 8.47 & 8.57 & 11.01 & 12.88 & 8.44 & 3.75 & 8.93 & 124.74 & 12,47 \\
\hline 2 & 313.10 & 30.39 & 21.04 & 18.49 & 9.15 & 9.24 & 11.81 & 13.92 & 9.14 & 4.07 & 9.75 & 136.99 & 13.70 \\
\hline 3 & 524.10 & 26.09 & 19.22 & 18.22 & 9.80 & 10.55 & 12.27 & 16.96 & 10.77 & 4.90 & 12.86 & 141.65 & 14.17 \\
\hline 4 & 1050.80 & 142.57 & 9.37 & 9.59 & 9.39 & 9.37 & 10.24 & 6.51 & 7.26 & 7.69 & 11.45 & 223.44 & 22.34 \\
\hline 5 & 485.90 & 245.28 & 36.15 & 38.73 & 38.28 & 37.39 & 41.51 & 26.94 & 29.65 & 31.45 & 47.98 & 573.34 & 57.33 \\
\hline 6 & 507.30 & 28.41 & 7.05 & 6.83 & 3.63 & 4.05 & 5.12 & 7.11 & 5.18 & 2.47 & 6.37 & 76.21 & 7.62 \\
\hline 7 & 220.90 & 14.45 & 4.29 & 3.87 & 1.66 & 1.65 & 2.29 & 2.70 & 1.85 & 0.83 & 2.08 & 35.67 & 3.57 \\
\hline 8 & 257.80 & 135.52 & 20.72 & 22.03 & 21.56 & 20.93 & 23.34 & 15.12 & 16.51 & 17.30 & 26.25 & 319.26 & 31.93 \\
\hline 9 & 1058.90 & 10.24 & 2.83 & 1.19 & 1.42 & 1.40 & 1.58 & 2.07 & 1.06 & 0.34 & 0.98 & 23.12 & 2.31 \\
\hline 10 & 379.10 & 7.75 & 2.30 & 0.97 & 1.31 & 1.22 & 1.42 & 1.84 & 0.89 & 0.29 & 0.81 & 18.81 & 1.88 \\
\hline 11 & 17.90 & 115.96 & 1.66 & 1.32 & 1.28 & 1.52 & 1.51 & 0.84 & 1.07 & 1.23 & 1.63 & 128.01 & 12.80 \\
\hline 12 & 382.70 & 18.23 & 5.42 & 2.27 & 2.52 & 2.60 & 2.89 & 3.82 & 2.02 & 0.64 & 1.89 & 42.30 & 4.23 \\
\hline 13 & 120.10 & 227.37 & 18.66 & 19.73 & 19.43 & 19.60 & 21.91 & 14.06 & 15.35 & 16.62 & 24.54 & 397.25 & 39.73 \\
\hline 14 & 462.20 & 13.14 & 1.86 & 0.74 & 0.95 & 0.91 & 1.06 & 1.39 & 0.68 & 0.22 & 0.60 & 21.55 & 2.16 \\
\hline 15 & 404.90 & 23.75 & 3.04 & 3.13 & 2.89 & 2.70 & 3.23 & 2.00 & 1.90 & 2.12 & 3.07 & 47.83 & 4.78 \\
\hline 16 & 101.90 & 20.07 & 0.87 & 0.33 & 0.22 & 0.23 & 0.20 & 0.31 & 0.19 & 0.05 & 0.16 & 22.64 & 2.26 \\
\hline 17 & 9.7 & 19.81 & 0.84 & 0.31 & 0.21 & 0.22 & 0.20 & 0.31 & 0.19 & 0.05 & 0.16 & 22.30 & 2.23 \\
\hline 18 & 358.20 & 40.03 & 4.49 & 1.79 & 1.58 & 1.79 & 1.88 & 2.59 & 1.47 & 0.44 & 1.36 & 57.42 & 5.74 \\
\hline 19 & 1643.60 & 98.32 & 36.60 & 17.73 & 12.77 & 15.65 & 16.18 & 21.47 & 12.40 & 4.49 & 13.50 & 248.12 & 24.81 \\
\hline 20 & 635.20 & 129.70 & 30.81 & 16.55 & 11.45 & 14.35 & 15.03 & 17.44 & 10.22 & 4.54 & 12.39 & 262.47 & 26.25 \\
\hline 21 & 359.90 & 80.35 & 13.00 & 6.32 & 4.43 & 5.22 & 5.10 & 5.81 & 3.86 & 1.73 & 5.05 & 130.90 & 13.09 \\
\hline 22 & 1332.90 & 232.61 & 62.60 & 34.08 & 23.48 & 29.25 & 31.06 & 36.42 & 21.49 & 9.80 & 26.69 & 507.47 & 50.75 \\
\hline 23 & 862.10 & 210.52 & 51.74 & 27.81 & 19.30 & 24.45 & 26.01 & 30.48 & 17.99 & 8.21 & 22.27 & 438.78 & 43.88 \\
\hline
\end{tabular}

Sourc: own study

Analysis by using AVSWAT 2000 produces the high value of erosion and sedimentation and it is almost the same as the filed condition. The condition is indicated that there is critical area which is spreading in the Kare District and the landslide which is caused by the high erosion. Based on the presentation as above, it can be concluded that the result of erosion and sedimentation analysis by using the AVSWAT 2000 can represent the filed condition.

\section{B. Erosion Danger Level (TBE)}

Analysis of the Erosion Danger Level (TBE) is carried out for knowing the class of erosion danger on a region by looking the happening erosion rate and the soil column depth. The percentage of Erosion Danger Level (TBE) in the Catur sub watershed is presented as in the Table- VI and VII.

Table-VI The Percentage of the Erosion Danger Level (TBE) in the Carur sub watershed Due to the land use of 2010

\begin{tabular}{|l|l|c|c|}
\hline \multicolumn{1}{|c|}{ No } & Erosion Danger Level (TBE) & Area (ha) & $\begin{array}{c}\text { Percentage } \\
(\%)\end{array}$ \\
\hline 1. & Light & $2,414.63$ & 20.93 \\
\hline 2. & Moderate & $6,176.56$ & 53.55 \\
\hline 3. & Heavy & $2,943.88$ & 25.52 \\
\hline Total & $11,535.06$ & 100.00 \\
\hline
\end{tabular}

Source: own study

Table- VII The percentage of Erosion Danger Level (TBE) in the Kare District

\begin{tabular}{|l|c|l|c|c|}
\hline Name of village & Area (ha) & \multicolumn{1}{|c|}{ TBE } & Area (ha) & Percentage (\%) \\
\hline Bodag & $1,462.38$ & Light & 496.323 & 7.430 \\
& & Moderate & 0.886 & 0.013 \\
& & Heavy & 965.167 & 14.449 \\
\hline Kuwiran & \multirow{2}{*}{65.73} & Light & 764.554 & 11.446 \\
& & Moderate & 79.571 & 1.191 \\
& & Heavy & 121.600 & 1.820 \\
\hline Kepel & $1,492.15$ & Light & 612.148 & 9.164 \\
& & Moderate & 880.002 & 13.174 \\
\hline Kare & $2,759.38$ & Light & 309.099 & 4.627 \\
& & Moderate & $2,450.284$ & 36.683 \\
\hline Total & $6,679.63$ & & $6,679.635$ & 100 \\
\hline
\end{tabular}

Source: own study

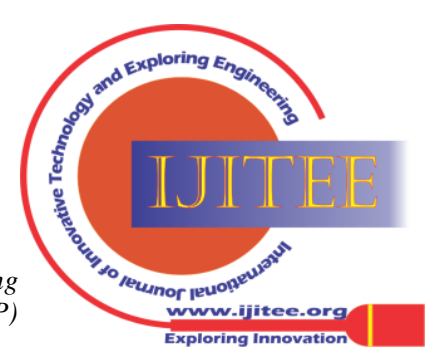




\section{Design of the Village Soil Conservation Planning (RKTD) \\ Bodag Village}

Plan of the conservation which will be carried out in the Bodag Village is the activity of conservation by using the vegetative method such as to arrange the land use in the Bodag village mainly in the Bodag small village due to the design of the Village Soil Conservation Planning is as follow:

a. Plantation of the alley cropping

Plantation of the alley cropping is a system which is the seasonal cropping (food and vegetable) is planted in the aisle between the fence cropping. The available fence cropping in the upstream Bodag is teak, "sengon", edible. The Forestry and Plantation Department of Madiun Regency has carried out the plantation of alley cropping such as leguminise and "kesambi" cropping. In the center of Bodag, the fence cropping can be as fruit like jackfruit and advocado because the two crops are good enough as the erosion controlling crop (it is due to the landslide). The "Kaliandra" and "lamtoro" crop will give the landslide potency if it is planted in the Bodag. The two crops are suitable to plant in the soil with the low fertility and has the soft texture.

\section{b. Soil cover vegetation}

The soil cover vegetation that is suggested is the type of legume spreading which is planted between the yearly vegetation in taking turn with the seasonal or yearly vegetation and as the pioneer vegetation for the rehabilitation of critical area in the Center Bodag area. Type of the vegetation which will be selected and functioned as the holding vegetation of landslide is the vegetation with the deep and large root. Type of the strip vegetation which will be selected is as grass or shrubs which is hoped to be planted as close as possible so it can hold the sediment that is produced from the erosion process.

\section{Kuwiran Village}

Plan of the conservation which will be carried out in the Kuwiran Village is the activity of conservation with the vegetative method such as to arrange the land use in Golang village due to the Village Soil Conservation Planning as follow:

\section{a.Plantation of alley cropping}

Plantation of the alley cropping which will be planted is leguminose and "kesambi" vegetation. In the center of Golang, the fence vegetation can be as fruits like durian, jackfruit, and advocado because these vegetation are good enough as the erosion controlling. The "Kaliandra" vegetation is planted in the Golang area where the landslide potency has. This vegetation is suitable to be planted on some types of soil included the acid soil with the low fertility and has the soft texture.

\section{b. Soil cover vegetation}

The soil cover vegetation that is suggested is the type of legume spreading which is planted between the yearly vegetation in taking turn with the seasonal or yearly vegetation and as the pioneer vegetation for the rehabilitation of the critical area in the Center Bodag area. Type of the vegetation which will be selected and functioned as the soil covering from the direct rainfall, the rehabilitation of the critical area, to keep the soil fertility and it can supply the organic material, Some kinds of the legume vegetation are as follow: "silo" (stylosanthes $s p$ ), "sentro" (centrosema sp), "kalopo" (calopogonium sp), and "puero/kudzu" (pueraria sp).Kare village

The proposed activity of the conservation which will be carried out in the Kare Village is the vegetative and mechanical conservation. The vegetative method is carried out in the Sweru Village by making effort to increase the trees and standing population in the shrubs area. The shrubs which covered the soil surface can protect the soil from the water scouring so it can decrease the erosion. Therefore, the effort that is nacessary to be carried out in this area with the area of 11 ha is to increase the tree population with the available types like "mahoni", "acasia", "sengon", banana, etc. The mechanical method is carried out in the Gondosuli village by developing two check dams (Check Dam I and Check Dam II). The dimension of check dam is presented as in the Table VIII and IX.

Table- VIII Recapitulation of the Check Dam I

\begin{tabular}{|l|l|c|}
\hline Symbol & \multicolumn{1}{|c|}{ Note } & Dimension $(\mathrm{m})$ \\
\hline $\mathrm{H}$ & Height of the main dam & 4 \\
\hline $\mathrm{B}_{1}$ & Overflowed width of the main dam & 3.2 \\
\hline $\mathrm{H}_{3}$ & Water depth over the spillway & 1 \\
\hline $\mathrm{B}$ & Width of the overflowed mercu & 2 \\
\hline $\mathrm{M}$ & Slope in the upstream weir & 0.3 \\
\hline $\mathrm{N}$ & Slope in the downstream weir & 0.2 \\
\hline $\mathrm{T}$ & Floor thickness of the stilling basin & 1 \\
\hline $\mathrm{L}$ & Floor length of the apron (stilling basin) & 10.5 \\
\hline $\mathrm{H}_{2}$ & Height of the sub dam & 1.2 \\
\hline
\end{tabular}

Source: own study

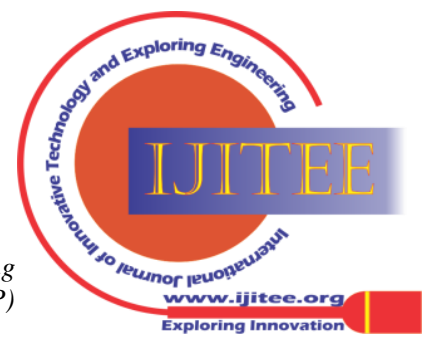


Table- IX Recapitulation of the Check Dam II

\begin{tabular}{|l|l|c|}
\hline Symbol & \multicolumn{1}{|c|}{ Note } & Dimension $(\mathrm{m})$ \\
\hline $\mathrm{H}$ & Height of the main dam & 3.5 \\
\hline $\mathrm{B}_{1}$ & Overflowed width of the main dam & 19.5 \\
\hline $\mathrm{h}_{3}$ & Water depth over the spillway & 1.2 \\
\hline $\mathrm{b}$ & Width of the overflowed mercu & 2 \\
\hline $\mathrm{m}$ & Slope in the upstream weir & 0.3 \\
\hline $\mathrm{n}$ & Slope in the downstream weir & 0.2 \\
\hline $\mathrm{t}$ & Floor thickness of the stilling basin & 1 \\
\hline $\mathrm{L}$ & Floor length of the apron (stilling basin) & 12.5 \\
\hline $\mathrm{H}_{2}$ & Height of the sub dam & 1.5 \\
\hline
\end{tabular}

Source: own study

\section{Kepel Village}

The Village Soil Conservation Planning in the Kepel Village is generally as the check dam which is located in the Kepel Village. Dimension of the Check Dam III is as in the Table$\mathrm{X}$.

Table- X Recapitulation of the Check Dam III

\begin{tabular}{|l|l|c|}
\hline Symbol & \multicolumn{1}{|c|}{ Note } & Dimension $(\mathrm{m})$ \\
\hline $\mathrm{H}$ & Height of the main dam & 3.5 \\
\hline $\mathrm{B}_{1}$ & Overflowed width of the main dam & 21.2 \\
\hline $\mathrm{h}_{3}$ & Water depth over the spillway & 1.2 \\
\hline $\mathrm{B}$ & Width of the overflowed mercu & 2 \\
\hline $\mathrm{M}$ & Slope in the upstream weir & 0.3 \\
\hline $\mathrm{N}$ & Slope in the downstream weir & 0.2 \\
\hline $\mathrm{T}$ & Floor thickness of the stilling basin & 1 \\
\hline $\mathrm{L}$ & Floor length of the apron (stilling basin) & 12.5 \\
\hline $\mathrm{H}_{2}$ & Height of the sub dam & 1.5 \\
\hline
\end{tabular}

Source: own study

\section{CONCLUSION}

Based on the analysis as above, it can be concluded as follow:

1. The analysis of erosion and sedimentation by using AVSWAT 2000 indicates that the Erosian Danger Level (TBE) is as follow:

- In the Bodag village is $7.43 \%$ light, $0.013 \%$ moderate, and $14.45 \%$ heavy

- In the Kuwiran village is $11.45 \%$ light, $1.19 \%$ moderate, and $1.82 \%$ heavy

- In the Kepel village is $9.16 \%$ light and $13.17 \%$ moderate

- In the Kare village is $4.63 \%$ light and $36.68 \%$ moderate.

2. The Village Soil Conservation Planning (RKTD) which will be applied in the Kare District is the vegetative and

- In the Bodag village is carried out the vegetative activity such as to arrange the land use with the vegetation of "sengon", "petai", teak, and grass.

- In the Kuwiran village is carried out the vegetative activity such as to arrange the land use with the vegetation of banan, "mahoni", teak, and grass.

- In the Kare village is carried out the vegetative and mechanical activity; the vegetative activity is carried out in the Sweru village such as to arrange the land use with the vegetation of banan, "mahoni", yam, "sengon", and grass; however the mechanical acitivity is to build the check dam in the Gondosoli village.

- In the Kepel village is carried out the mechanical activity by building the check dam in the Kepel village. mechanical methods as follow:

3. The check dam will be built in the Kepel and Kare villages. There are two check dams are built in the Kare village and one check dam in Kepel village.

\section{REFERENCES}

1. L.M. Hermans, "An Approach to support learning from international experience with water policy", Journal of Water Resource Manage (25): 373-393, 2011

2. P.T. Juwono, L.M. Limantara, W. Soetopo, and A. Nopebrian, "Optimization of irrigation cropping pattern", International Journal of Geomate, Vol. 15 (50): 197-204, 2017

3. L.C. Chia and H.H. Chung, "Applying a modified VIKOR method to classify land sub-divisions According to watershed vulnerability", Journal of Water Resource Manage (23): 301-309, 2011

4. L.M. Limantara, "Optimization of improvement and management on Sumber Brantas watershed, East Java, Indonesia”, Journal of Basic and Applied Scientific Research. Vol. 1(3(: 231-235, 2011

5. L.M. Limantara, M. Bisri, and R. Fajrianto, "Optimization of water usage at irrigation area of pakis-malang rehency-indonesia by using linear programming", International Journal of Engineering and Technology, Vol. 7\{4\}: 6432-6436, 201

6. J.M. Hooke, "An analysis of the processes of river bank erosion", J.Hydrol., 42, 39-62, 1979

7. J.S. Bridge, "Rivers and floodplains: forms, processes, and sedimentary record", Blackwell, Malden, Mass, USA, 2003

8. A. Simon and R.E. Thomas, "Processes and forms of an unstable alluvial system with resistant, cohesive streambeds, earth surf'. Proc. Land., 27, 699-718, 2002

9. C. Asdak, "Hidrologi dan pengelolaan daerah aliran sungai (edis kedua) (Hydrology and watershed management)" . Gadjah Mada University Press.Yogyakarta, 2004

10. S. Arsyad, "Konservasi tanah dan air (Soil and water conservation)", IPB. Bogor, 2000

Published By:

Blue Eyes Intelligence Engineering and Sciences Publication (BEIESP

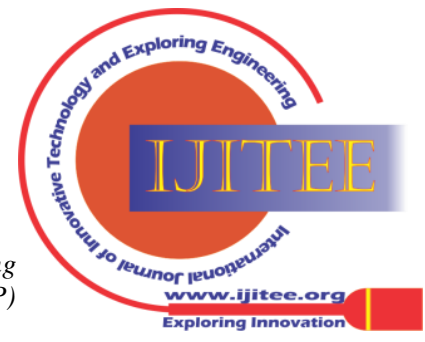


11. E.A. Varouchakis, G.V. Giannakis, M.A. Lilli, E. Ioannidou, N.P. Nikolaidis, and G.P. Karatzas, "Development of a statistical tool for the estimation of riverbank erosion probability", Soil, 2: 1-11, 2016

12. E. Suhartanto, "Panduan AVSWAT 2000 dan aplikasinya di bidang teknik sumberdaya air (Manual guide of AVSWAT 2000 and the application in the water resources)", Malang: CV Asrori, 2008

13. W.H. Utomo, "Erosi dan konservasi tanah (Erosion and soil conservation)", Malang: IKIP Malang, 1994

14. M. Bisri, "Water conservation mapping at Kali Sumpil", International Journal of Academic Research. Vol 2(5); 156-158, 2010

15. L. Holko and A. Lepsito, "Modeling the hydrological behavior of mountain catchment using TOPMODEL", Journal Hydrology 196 361-377, 1997.

16. B. Satyagraha, M. Bisri, L.M. Limantara, and U. Andawayanti, "Model of water economic value optimization based on the land use change", Journal of Water and Land Development, 36 (I-III): 143-152, 2018

17. P.H. Verburg, and A. Vedkamp, "Projecting land use transactions at forest in Philippines at two spatial scales", Landscape Ecology, Vol 19, pp. 77-98, 2004

18. P.L. Yu, M.H. Nien, J.W. Pei, F.W. Chen, and P.H. Verburg, P. H, "Impacts of land use charge change scenarios on hydrology and land use patterns on the Wu-Tu watershed in Northern Taiwan", Environmental Informatics, 2005

19. SNI 03-2851-1991, "Tata cara perencanaan teknis bendung penahan sedimen (Regulation of weir technical design)", 1991

\section{AUTHORS PROFILE}

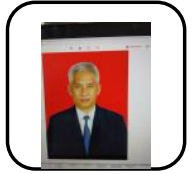

Mohammad Bisri, Lecturer on the Department of Water Resources, Faculty of Engineering, University of Brawijaya, Jl. Mt Haryono No 167 Malang, Indonesia Email: mbisri@ub.ac.id

Ery Suhartanto, Lecturer on the Department of Water Resources, Faculty of Engineering, University of Brawijaya, Jl. Mt Haryono No 167 Malang, Indonesia Email: erysuhartanto@yahoo.com

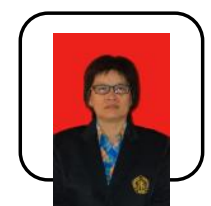

Lily Montarcih Limantara, Lecturer on the Department of Water Resources, Faculty of Engineering, University of Brawijaya, Jl. Mt Haryono No 167 Malang, Indonesia Email: lilymont2001@gmail.com

Marina Putri Prastuti, undergraduate student on the Department of Water Resources, Faculty of Engineering, University of Brawijaya, Jl. Mt Haryono No 167 Malang, Indonesia. Email: putriprastuti@gmail.com

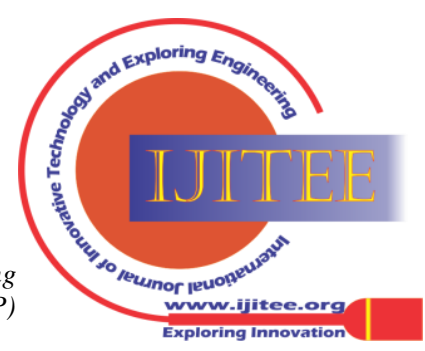

